\title{
Service recovery in a cruise line context - A study on the Norwegian coastal voyage (Hurtigruten)
}

\author{
Hugo Skaalsvik ${ }^{1 \star}$
}

Reveived: 25/11/2010 Accepted: 18/06/2011

\footnotetext{
${ }^{1}$ Department of Business Administration and Social Sciences, Harstad University College, Havnegata 5-7, 9480 Harstad, Norway, email: hugo.skalsvik@hih.no

* Corresponding author
}

\begin{abstract}
This paper reports on a study on service recovery carried out on the prestigious Norwegian Coastal Voyage (NCV) or the Hurtigruten which is the brand name. The exploration is based on a collection of 51 service failure incidents of which 16 were recovered by the service provider. This paper describes the service recovery actions made by the service provider and discusses components of effective service recovery by focusing on the role of service employees.
\end{abstract}

(C) 2011 International University College. All rights reserved

Keywords: Service recovery, qualitative research, case study research, service employees, the Norwegian Coastal Voyage, Hurtigruten.

Citation: Skaalsvik, H. (2011) Service recovery in a cruise line context - A study on the Norwegian coastal voyage (Hurtigruten). European Journal of Tourism Research 4(2), pp. 157-179

\section{Introduction}

This paper documents a study on the Norwegian Coastal Voyage (NCV) or the Hurtigruten which is the brand name (see Appendix 1 for informative details). Even though the research stream of service recovery has been examined for some time, academic research on this topic is relatively recent and still in progress and the knowledge base needs to be further developed and advanced (e.g. Lewis and McCann, 2004; Michel et al., 2009). To examine service recovery in the cruise line industry, and particularly on the Hurtigruten, is especially relevant and interesting as the cruise line industry is gradually progressing in economic importance (Biederman, 2008).
Research on service recovery is closely coupled to research on service failures (Grönroos, 2006; Skaalsvik, 2011). According to Grönroos (1988), service recovery concerns the action which a company takes in response to a service failure. A service failure is "a breakdown in the delivery of service; service that does not meet customer expectations" (Hoffman and Bateson, 1997:327). This implies that service recovery management constitutes an important part of effective services management (Grönroos, 2006).

Service failures are an inevitable part of service processes and occur in both the process and outcome of service delivery (Lewis and McCann, 2004). Thus, the effective 
management of service failures is important for service quality improvements (Bejou and Palmer, 1998). From the tourists' point of view, the most immediate evidence of the service quality occurs in the service encounters or in the "moments of truth" when the tourists interact with the service personnel (e.g. Czepiel, 1990). As a people intensive service industry, the cruise line industry is featured by a high degree of interactions between the service employees and the tourists, and there are many opportunities for service failures to occur during phases of service delivery. If service failures occur, and they will, they have to be adequately handled and managed by the service provider by the use of effective service recovery management (Michel et al., 2009; Tax and Brown, 1998).

This study aims to explore the service recovery actions or strategies which were used in a set of service failure situations on the Hurtigruten as "an important but often forgotten management tool is the art of service recovery" (Hoffman and Bateson, 1997: 335). According to Johnston and Michel (2008), many organisations need to develop their recovery programmes and procedures.

The study addresses two questions:

1. What service recovery actions were used by service provider in order to correct a set of service failure incidents on the Hurtigruten?

2. What are important components of effective service recovery?

The first research question is answered by providing a set of descriptive accounts of the service recovery actions or strategies which were identified and used by the service provider as responses to a set of service failure incidents on the Hurtigruten. The second research question is answered by offering a discussion of components which are considered important for effective service recovery management. In the discussion, an emphasis will be on the role of the high-contact employees (Lovelock and Wright, 1999). As will be revealed in this paper, a set of service failure incidents were not recovered by the service provider. However, it is beyond the scope of this paper to explain why these incidents were not recovered. This topic will be discussed in a separate paper.

In order to answer the research questions raised, the paper is organised into seven parts. Following this introduction, the second part briefly describes the empirical context of the study in order to provide information on the contextual uniqueness of the Hurtigruten. Part 3 constitutes a review of the empirical research on service recovery particularly linked to the research questions posed. In part 4, the methodology details are outlined and discussed while part 5 entails the research findings. A discussion of the research findings follows in part 6. In this part, a discussion of the components of effective service recovery is offered which particularly addresses the decisive role of services employees' for effective service recovery. Part 7 ends the paper by addressing the implications of the research findings and draws a series of conclusions. The limitations of the study are discussed in this part and further research is suggested.

\section{Empirical context}

The context of the study is interesting due to historical-, cultural-, geographical- and tourism factors. Historically, the Hurtigruten has offered transportation along the long Norwegian coast since 1893. Culturally, the Hurtigruten has provided pride and identity to the scattered coast line population in Norway, as well as geographically in the sense that the Hurtigruten has united the coastal settlements along the long Norwegian coast from Bergen to Kirkenes. (See map in Appendix 1 for geographical orientation). However, it is the tourism dimension that brought this research into reality. As a consequence of heavy investments in new ships in the early 1990s which appear to look like conventional smaller explorer cruise ships, the tourists' portion of the travellers on the Hurtigruten has gradually increased in numbers as well as in economic importance. As a consequence of a merger of two shipping lines in 2006, there is one cruise line company in operation today, the Hurtigruten ASA. The management of the company has set the ambitious strategic goal of becoming a world leader in explorer cruises 
within 2012. According to Heskett et al., (1994), a goal like this requires a focus on quality in order to compete effectively in environments termed “hyper-competition” by D’Aveni (1994).

\section{Literature review}

Research on service recovery is closely linked to research on service failures (e.g. Lewis and Clacher, 2001; Lewis and McCann, 2004; Michel et al., 2009; Skaalsvik, 2011). Recovery research has focused on several conceptual-, theoretical- and practical issues in a diverse set of service industries (e.g. Miller et al., 2000; Zemke and Connellan, 2001; Duffy et al., 2006). However, more research is still needed on effective recovery management (Michel et al., 2009), as service providers are slow to respond to and correct service problems when customers complain (Gross et al., 2007, Tax et al., 1998). According to Hart et al., (1990), over half of the businesses responses to complaints actually strengthened the customers' negative feelings and attitudes towards the service provider, which implies a decline in customer confidence (Boshoff and Leong, 1998). This is a threat to service performance and implies the need for effective recovery management (Lewis \& Spyrakopoulos, 2001; Michel et al., 2009).

\section{Service recovery: Understanding the concept}

Service recovery has been used as a concept to describe the process of how to seek out and deal with service failures (Hoffman \& Bateson, 1997; Matilla, 2001). Mattila (1999:284) expresses this simply: "Putting right what has gone wrong". Lovelock and Wright (1999:141) perceive service recovery as "a systematic effort by a firm after a service failure to correct a problem and retain a customer's goodwill". The essence is that if something goes wrong during stages of service delivery, management should make efforts to recover from the service failures because a good recovery can turn dissatisfied customers into satisfied and loyal ones (Hart et al., 1990; Brown et al., 1994; Maxham, 2001). Miller et al., (2000:38) perceive service recovery as "those actions designed to resolve problems, alter negative attitudes of dissatisfied customers and ultimately retain these customers". Thus, the core is to keep and enhance the customer's trust in the service provider after service breakdowns.

Michel et al., (2009), however, have suggested an even more comprehensive understanding of service recovery, and perceive service recovery as "the integrative actions a company takes to re-establish customer satisfaction and loyalty after a service failure (customer recovery), to ensure that failure incidents encourage learning and process improvement (process recovery) and to train and reward employees for this purpose (employee recovery)." This definition brings new elements to the understanding of service recovery by focusing on a set of recovery concepts. By building on Johnston and Michel (2008), Michel et al., (2009) argue that three different, discipline-linked perspectives are needed in order to understand service recovery management, those of customer-, process- and employee recovery. This implies that an integrated approach to service recovery is required.

In this paper, both customer- and employee recovery are dealt with as the first research question focuses on customer recovery by describing a set of service recovery actions or strategies used by the service provider in order to please, satisfy and retain the customers, and the second research question focuses on employee recovery by discussing what components are required in order to support employees and to help them to recover from service failures.

\section{Researching service recovery}

As evidenced in service research, the cost of failing in service processes is the "cost of quality" which may be damaging for any service provider (e.g. Zeithaml et al., 1996), for example the risk of losing customers (Keaveney, 1995) because dissatisfied customers "vote by their feet" (Matilla, 1999:286), negative "word of mouth" (e.g. Susskind, 2002; Swanson and Kelley, 2001), decreased employees' satisfaction and morale (Bitner et al., 1994), reduced customer satisfaction (Smith et al., 1999; Zeithaml et al., 1996), a decline in customer confidence (Boshoff and Leong, 1998), a decrease in 
customer loyalty (e.g. Bejou and Palmer, 1998; Maxham, 2001; and Maxham and Netemeyer, 2002), lost customer lifetime value (Rust et al., 2000) and ultimately a loss of revenue and increased costs (Armistead et al., 1995). Thus, a shift to a quality focus seems essential to the competitive survival of service businesses (Heskett et al., 1994; Johnston, 2001) which implies that service organisations need capacity, competency and management tools to recover from service failures when they occur.

Hence, several authors (e.g. Etzel and Silverman, 1981; Bell and Zemke, 1987; Berry and Parasuraman, 1992; Eccles and Durand, 1998; McDougall and Levesque, 1999; Grönroos, 2000; Bamford and Xystouri, 2005; Michel et al., 2009; among others) have emphasised the benefits to recover well from service failures. Berry and Parasuraman (1992), for example, suggested that organisations should consider service failures or defaults not necessarily as problems but as opportunities to create satisfied and loyal customers. As another example, Bamford and Xystouri (2005), emphasised that the effective handling of service failures plays a vital role in maintaining and building customer loyalty. According to Etzel and Silverman (1981), effective recovery actions can lead to customers having more positive attitudes and feelings towards the organisation than had the transaction been performed correctly the first time. This is a situation termed the "service recovery paradox" (Grönroos, 1988). According to Maxham and Netemeyer (2002), the "service recovery paradox" may work in one failure situation but is unlikely to work after two failures. However, (good) service recovery actions are needed in order to recover effectively from service failures because successful service recovery may have a set of significant benefits such as building trustful customer relationships (e.g. Spreng et al., 1995; Michel 2001). However, the extent of success may depend on the type of service, the type of failure, the speed of the response, service employee involvement and customer relationship (e.g. Mattila, 2001; McDougall and Levesque, 1999; Boshoff, 1997; Duffy et al., 2006 and Craighead et al., 2004).

\section{Service recovery actions}

Over time, an extensive literature on service recovery is developed in the service research community on a diverse set of issues. One issue of interest in academia and practice is what recovery actions or strategies are considered effective in restoring customer satisfaction and retaining customer loyalty. Hoffman and Bateson (1997) suggest that responses to service failures can be categorised into two different groups:

- Responses to service failures that are attributed to the service organisation, - Responses to service failures that are attributed to customer error.

In both groups there are two options, good responses and poor responses. Illustratively, according to Hoffman et al., (1995), and acceptable economic compensation is the most desired response by customers. Similarly, a poor response is when the service personnel fail to accept and recognise the seriousness of the problem(s) raised by the customers.

A set of previous empirical studies has focused on components of effective recovery (e.g. Bell and Zemke, 1987; Bitner et al., 1990; Kelley et al., 1993; Johnston, 1995; Boshoff, 1997; Hoffman et al., 1995; Hoffman and Chung, 1999; McDougall and Levesque, 1999; Goldstein et al., 2002; and Boshoff and Staude, 2003). Bell and Zemke (1987), for example, proposed five components for an effective recovery strategy: apology, urgent reinstatement, empathy, symbolic atonement and follow up. Johnson (1995) focused on three components: service employees showing empathy, giving adequate information and acting, while an important finding in the McDougall and Levesque (1999) study was that the recovery strategies of assistance plus compensation had the greatest positive effect on customer's future intentions towards the service provider. Boshoff and Staude (2003) emphasised that the satisfaction with service recovery was impacted positively by good communication, a proper explanation and atonement.

The empirical research reveals that the most common and frequently used efforts or actions 
are an apology for the situation, assistance and/or economic compensation. Assistance for example, involves actions which are taken to rectify the service problem, while compensation involves monetary payments for the inconvenience the customer has experienced. When service failures occur and customers complain, the complaints are often communicated to the front line employees who are expected by the complainers to respond and act quickly (Bettencourt and Gwinner, 1996). Thus, the role of service employees in the service recovery process is crucial in order to enhance service performance (e.g. Lewis and Spyrakopoulos, 2001; Miller et al., 2001; Duffy et al., 2006).

Service recovery and the role of service employees

Most service organisations are aware of the value of well planned external recovery, or customer recovery (Johnston, 2001). However, far less are aware of the importance and the effects of well planned internal service recovery, or employee recovery. A good internal service recovery may lead to satisfied and passionate customers because service employees are performing well in their service roles, while poor internal service recovery may lead to dissatisfied and disillusioned customers due to stress-filled and negatively disposed service employees who feel, more or less, helpless in their service roles (Johnston and Clark, 2008). Thus, by building on Bowen and Johnston (1999), Michel et al., (2009) suggest that the practise of internal recovery may limit the negative "spillover" from employees to customers (Pugh et al., 2002; Schneider and White, 2004). According to Maxham and Netemeyer (2002), this implies that service managers must treat employees in the same manner as they want the employees to treat the customers. Therefore, if service employees feel ill-treated by their superiors, the employees may feel so alienated that they simply sabotage the service by showing deviating service attitudes and behaviour. Seligman (1972) termed this as "learned helplessness" which may result in passive, unfriendly and maladaptive service behaviours by service employees. In a situation like this, the employees will expose negative commitment to customer service (Bell and Luddington, 2006). Effective employee recovery may lead to higher service employees' job satisfaction and lower intentions to quit (Boshoff and Allen, 2000). According to de Jong and de Ruyter (2004), employee job tenure is positively related to effective service recovery.

In a large study conducted by Bitner et al., (1990), a key finding was that the responses of high contact employees were critical in determining the result of service failures. This is in accordance with Hoffman and Bateson (1997:335) who emphasise that "a customer will remember the service encounter favourably if the service personnel respond in a positive manner". Similarly, effective service recovery may have a positive effect on service employees' attitudes towards providing service excellence (Johnston, 2001). Zemke and Connellan (2001) emphasise the role of service employees and argue that the employees must "fix" the customer before they "fix" the service problem. Hence, trained, knowledgeable and cooperative service employees will not engage in service sabotage, but will act proactively in order to obtain better service performance (Durvasuta et al., 2000; Harris and Ogbonna, 2006).

Employee recovery then focuses on what service management can do in order to help employees succeed in attempting to recover customers after the occurrence of service failures or their actions to help employees to recover themselves from negative feelings in service failure situations. The suggestion in this paper is that if the service employees possess appropriate competencies and are empowered in their service roles, two components for effective employee recovery will be in place (Grönroos, 2006). Inspired by Yukl (2002), the concept of competencies is perceived at the actors, in this case the service employees, possessions of knowledge, skills, attitudes and their actual behaviours in performing the service roles.

Different opinions exist in the research literature on what constitutes empowerment. According to Lovelock and Wright (1999:330), empowerment concerns "authorizing the 
employees to find solutions to service problems and to make appropriate decisions about responses to customers' concerns without having to ask for supervisors' approval". This definition entails an element of improvisation. Despite any disagreement of understanding the concept, a key wisdom is that empowered employees with discretion and authority to fix problems in real-time is the key to effective recovery (Michel et al., 2009). According to Lorenzoni and Lewis (2004:11), "empowerment is the most powerful tool for effective service recovery". However, as pointed out by Goodwin and Ross (1990), as empowerment is individualistic and "belongs" to the service employee, there is a risk that the customer perceives that the recovery solely depends on the employee and that in order to have their complaint resolved satisfactorily, the complaint has to be handled by the "right" employee. This implies the perception that effective recovery is a about being "lucky" with the service attendant and not about fairness in general. Nevertheless, the responses of service employees are crucial in effective service recovery management (e.g. Bitner et al., 1990; Michel et al., 2009).

\section{Methodology}

Service failure and recovery data may be collected by means of different methods (Michel et al., 2009). One option is by collecting critical service incidents which utilise the advantages of qualitative studies. The essence is that the respondents can provide descriptive accounts in their own words of the incidents causing them to be satisfied or dissatisfied (Grove and Fisk, 1992).

In this study, the Critical Incident Technique (CIT) guided the research. The CIT was originally developed for research purposes by Flanagan (1954). In diverse research settings, the CIT methodology has proved to be useful and applicable when the aim has been to enhance knowledge about a phenomenon about which relatively little is known (Bitner et al., 1990; Bejou et al., 1996). According to Chung and Hoffman (1998), the CIT methodology is primarily a classification technique which analysis critical incidents. Critical incidents are events that can be described in detail and provide information on what the customers expect or consider normal in service encounters. According to Krippendorf (1980), the CIT employs content analysis of "stories" or "anecdotes" as data.

In the study, a case study approach was favoured (e.g. Mehmetoglu, 2004; Merriam, 1998; Yin, 2003). According to Gummesson (2000), the case study approach is particularly useful when examining a phenomenon about which relatively little is known and gradually the case study approach has gained more respectability within the management research area.

Empirical data can be collected from both primary- and secondary data (Booth et al., 2003). Internal reports provided insight and understanding of the Hurtigruten as a composite tourist attraction product. In a strategic report entitled, "Strategic Choices after 2001" (Hurtigruten, 1999), a strategy of becoming an explorer cruise line company is discussed. In order to become more competitive internationally, a set of service quality issues are addressed, e.g. how to become a market leader in explorer cruises. However, according to Kinnear and Taylor (1991), secondary data may lack precision. Primary research information can offer more targeted and extensive data from subjects who can provide information to the questions under scrutiny (Veal, 2006).

The research reported in this paper is carried out from the viewpoint of the service employees', a perspective which in previous research has proved to be a reliable alternative to the customers' perspective. The service employee perspective values the decisive role of service employees for effective service encounters (Bettencourt and Gwinner, 1996; Lewis and Entwistle, 1988).

On the Hurtigruten, a set of service employees work. According to service management theory, both front stage and back stage service personnel are decisive for superior service performance (Kandampully, 2007). For many tourists, however, the tour conductors are simply the service due to the many service 
encounters with the tourists. For many complaining tourists, the tour conductors are the "contact point" as to when to provide information on what has caused them to be dissatisfied with the service offering. Similarly, the tour conductors are good observers and sources of information regarding what the service provider did, or did not do, in order to recover from the service failure incidents. Thus, in this study the tour conductors are the selected informants on the service recovery actions or strategies which were used by the service provider.

By contacting the shipping line's personnel department, the department released a tour conductor's list which consisted of 13 conductor names divided in two separate groups, consisting of regulars and substitutes. In order to obtain reliable information on the use of recovery actions in service failure situations, a choice was taken to include only the regulars in the sample due to their expertise in service operations on the Hurtigruten. The regulars consisted of eight persons. After being contacted, one of them, a man, did not want to participate in the investigation as he opposed the strategic change of direction of the Hurtigruten to become an "ordinary" cruise ship. His choice was of course accepted and no pressure was put upon him to change his decision.

A decision had to be taken regarding what data collection technique which was considered most suitable for collecting information on the service recovery actions which were used by the service provider. According to Fielding (1997), the personal interview is the most commonly used method of data collection. A decision was taken to employ this data collection technique due to the connection to the CIT methodology, the small sample of informants and the fact that the research questions under scrutiny required intensive access and closeness to the respondents.

An interview guide served as an information gathering tool. For the purpose of this paper, the question "what did the service provider do in order to correct the service failures or service breakdowns"?, is directly addressing the first question. Following the analytical attempt to answer the first question, the second research question is answered by offering a discussion on important components of effective service recovery which values the decisive role of service employees. The interviews with the tour conductors were conducted in August and September 2001. The long interviews (McCracken, 1988), each interview lasting for approximately two hours, was administered by the author.

A decision then had to be taken on how to carry out the interview process. First, the tour conductors were contacted in writing in order to explain the purpose of the research and to encourage them to join the research as respondents. Secondly, the tour conductors were contacted by telephone in order to obtain their formal approval and to obtain an agreement as to when to carry out the formal interviews. In the course of the telephone conversations, the tour conductors were encouraged to try to recall incidents of service failures and associated recoveries, write down the details, and bring with them the notes to the formal interview meeting. Third, the long interviews with the tour conductors were carried out when the Hurtigruten was at sea between the towns of Harstad and Svolvær (see map in Appendix 1 for geographical information). During this part of the voyage, the tour conductors had the time available to fully concentrate on the interview situation as this part of the journey starts quite early in the morning and most of the tourists were occupied with breakfast and some of them participate in an excursion between Harstad and Sortland. In the course of the interviews, the tour conductors orally provided 7 to 8 descriptive accounts of service failures and associated recoveries. The interviews were tape recorded which made it possible to listen again to the informative information which the tour conductors had provided and interview transcripts were made.

In this case study, the analysis part of the methodological approach consists of a grouping system which attempted to categorise the service recovery actions or strategies within a given set of categories. As similar attempts 
had been previously carried out in a diverse set of service industries, the newness of the study is the empirical context; an actor in the explorer cruise line industry. Nevertheless, as in all qualitative research, there is an element of creativity involved in the analysis process (e.g. Johannessen et al., 2004). The categories of service recovery that emerged from a thorough examination of the interviews are presented in the findings section of this paper.

The issue of quality in research needs consideration (Gummesson, 2000). There are several opinions on how to secure quality in quantitative studies (e.g. Johannessen et al., 2004). Veal (1997) discusses the two axioms of research quality, validity and reliability. Validity is perceived as "the extent to which information collected by the researcher truly reflects the phenomenon being studied" (Veal, 1997:35). The research phenomenon in this study is the service recovery actions or strategies which were used by the service provider after the occurrence of a set of service failure incidents on the Hurtigruten. The validity of the research findings is closely linked to the tour conductors' recall and report of the recovery actions which were used in a set of service failure situations. As the tour conductors were given much time to recall and rethink service recovery actions, the information collected provided a "pattern" or "system" of recovery actions in that specific context. Reliability is perceived by Veal (1997:35) as "the extent to which research findings would be the same if the research was to be repeated at a later date with a different sample of subjects". However, as the intention of a single case study "is not to make generalisation but to investigate a "one off situation" (Clark et al., 1998:103), the case study may contribute to the knowledge field of service recovery but is restricted to a specific context.

Any empirical study involving people needs ethical considerations (e.g. Johannessen et al., 2004). Nerdrum (1998) discusses three issues which a researcher needs to consider which are particularly relevant for collecting information from people, e.g. by means of indepth interviews as in this research. First, the right to self determination and autonomy, secondly, to respect privacy, and thirdly, to avoid personal damage. In the research reported in this paper, the first issue is particularly relevant. The respondents were not under any pressure to participate in the research as they voluntarily joined in. In the course of the in-depth interviews, the respondents told the "stories"/"anecdotes" of recovery actions in their own words without any interruptions from the researcher. Each participant was also informed that (s)he could decide to leave the interview for any reason and that the information which was provided would be treated anonymously. To the best of our knowledge, the research has not harmed the respondents in any way.

\section{Findings}

During the data collection phase, the data on 51 service failure incidents and associated recoveries were collected. In Appendix 2, a list of 51 service failures and associated recoveries are provided and key words are used in order to describe what actually happened in the service failure situations. The 51 service failure "stories" or "anecdotes" were identified within two distinct areas:

1. Service failure incidents on excursions: 22 incidents

2. Service failures on the Hurtigruten while at sea or at harbour: 29 incidents.

\section{Service failures: Organisation structure}

In order to organise and structure the service failure incidents even further, a procedural process started with a repeated and careful reading and categorisation of the 51 service failure incidents into sub categories according to the similarities in the reported experiences. The following sub categories on excursions emerged:

- Competency failures (9 incidents)

- Information failures (4 incidents)

- Customer error failures (3 incidents)

- Service failures in core delivery (3 incidents)

- $\quad$ Other service failure incidents (3 incidents)

Competency failures encompass service failure incidents caused by the service personnel due to a shortage in core service competencies. 
Information failures consist of service failure incidents caused by incorrect information given to the tourists from the service provider. Customer error failures encompass service failure incidents caused by the tourists' own shortcomings. Service failures in core delivery consist of service failures caused by shortage in the core service offerings. The sub category other service failure incidents is a ragbag category and consists of service failure incidents on excursions that cannot be allocated to the other four sub categories. Thus, the first main category: Service failures on excursions consist of five sub categories of which competency failures constitutes the largest at approximately $40 \%$ of the incidents.

The following sub categories on the Hurtigruten (while at sea or at harbours) emerged:

- Customer needs and requests (10 incidents)

- Tourists attitudes and behaviours (8 incidents)

- Jay customers (2 incidents)

- Service personnel competency (3 incidents)

- Information failures (2 incidents)

- Failures in core delivery (4 incidents)

Customer needs and requests encompass service failure incidents where the tourists raise needs and requests to which the service employees have to respond. Tourists' attitudes and behaviours consist of service failure incidents caused by the tourists' themselves. Jay customers are the highly "problematic", unpleasant and embarrassing customers (Lovelock and Wright, 1999). Service personnel competency consist of service failure incidents caused by a shortage in service employees core service competencies. Information failures consist of service failure incidents caused by incorrect information given to the tourists from the service provider. Service failures in core delivery consist of service failure incidents caused by shortages in the core service offering. The service provider simply does not deliver the service product as promised. Thus, the second main category: Service failures on the Hurtigruten while at sea of at harbours consist of six sub categories of which the category customer needs and requests constitutes the largest one at about $34 \%$ of the incidents.

The categorisation of the service recovery actions:

Next, a process was started to organise the service recovery actions which were implemented and used by the service provider in a set of the service failure situations. An examination of the 51 service failure incidents revealed that 16 recovery actions were implemented and used by the service provider; with 8 recovery actions in each of the two main categories, on excursions and on the Hurtigruten while at sea or at harbour(s). Table 1 and Table 2 below illuminate that three different recovery actions were implemented by the service provider. The actions were economic compensation, service personnel assistance and upgrading of the core delivery.

Economic compensation implies that the complainer(s) is/are refunded the personal outlay. Service failure incident no. 16 illustrates the situation. A descriptive account of the incident will be provided later in the paper. Service personnel assistance implies that the service employee(s) did something actively in order to please and satisfy the complainer(s). Incident no. 17 illustrates the situation. A description of the incident will be provided later in the paper. Upgrading the core delivery implies that the complainer(s) receive(s) more than they originally paid for. The service failure incident no. 23 illustrates the situation. A descriptive account will follow in the next section of the paper.

Illustratively, Table 1 reads as follows: two competency failures on excursions, the service failure incidents no. 16 and 48, were recovered by economic compensation. Two customer error failures, service incidents nos. 10 and 49, were recovered by economic compensation as well. Recovered by service personnel assistance was the service failure incidents nos. 17, 22 and 2, which belong to three different service failure sub categories. Service failure no. 23, which was categorised as a failure in core delivery was compensated by upgrading the core delivery. 
Service recovery in a cruise line context - A study on the Norwegian coastal voyage (Hurtigruten).

Table 1. Service recovery actions on excursions

\begin{tabular}{|l|c|c|c|}
\hline \multirow{2}{*}{ Service Failure Subcategory } & \multicolumn{2}{c|}{ Recovery Actions } \\
\cline { 2 - 4 } & $\begin{array}{c}\text { Economic } \\
\text { compensation }\end{array}$ & $\begin{array}{c}\text { Service personnel } \\
\text { assistance }\end{array}$ & Core delivery \\
\hline Competency Failures & No. 16, No. 48 & & \\
\hline Information Failures & & No. 17 & \\
\hline Customer Error Failures & No. 10, No. 49 & No. 22 & No. 23 \\
\hline Service Failures in Core Delivery & & No. 2 & \\
\hline
\end{tabular}

Descriptive accounts of service recovery actions on excursions

Recovery action: Economic compensation

Four service failure incidents on excursions were recovered by economic compensation. The failures were classified within two service failure sub categories: competency failures and customer error failures. Descriptive accounts of the service failure incidents will be described next.

Competency failures recovered by economic compensation

The two stories reported, no. 16 and no 48, both concerned overbooking of excursions to the popular Svartisen Glacier due to failures made by the service employees as the participants' lists were manually handled. In this way, the number of tourists' to participate on the excursion came out of "control". In both cases, the tourists who could not participate due to the capacity limits of 60 tourists, had to be refunded their outlays. However, according to the interviewees, the tourists were not compensated beyond the price of the excursion. Thus, the participants got their money back but, according to the tour conductors, this was not enough to ease their frustration and anger towards the service provider as the excursion to the Svartisen Glacier is highly valued by the tourists.

\section{Customer error failures recovered by economic} compensation

Two service failure stories that were recovered belong to the customer error failure category. The incidents, no. 10 and no. 49, were recovered by economic compensation. In both cases, the participants did not show up when the buses were ready for departure. In principle, this was completely the tourists' own fault. However, according to the tour conductor, the tourists were dissatisfied because nothing was done to take contact with them before the departure; e.g. by calling the tourists up on the ships' loud speaker system. According to the tour conductor, the service provider was not obliged to refund the excursion tickets but they did so in order to avoid further dissatisfactions and further complaints from the tourists.

Recovery action: Service personnel assistance Three service failure incidents, no. 17, no. 22 and no. 2, were recovered by service personnel assistance. The recoveries belonged to three different service failure sub categories (see Table 3 for informative details).

Information failures recovered by service personnel assistance

One service story only is reported in this category, no. 17. On an excursion from Molde to Kristiansund, the bus broke down and the tourists had to wait for another bus. According to the tour conductor, the problem that arose was the lack of information on what would happen next; e.g. when would a new bus arrive and pick up the participants? According to the tour conductor, the service personnel did what they could in the situation by providing information and communicating with the tourists. However, according to the interviewee, the shortage of up dated reliable information turned the participants into a state of dissatisfaction with the recovery.

Customer error failure recovered by service personnel assistance

Service failure story no. 22 concerned a lady who had lost the medicine prescription which she claimed had been removed by the cleaning lady. According to the tour conductor, the lady turned into a very satisfied tourist as she was effectively assisted in obtaining a new prescription upon arrival in a town up north. 
Thus, this is an example of the "service recovery paradox", the complainer is more satisfied than if the service failure had not taken place at all.

Service failures in core delivery recovered by service personnel assistance

Service failure story no. 2 was recovered by service personnel assistance. The story was about a tourist couple from Germany who complained when a dinner was supposed to be served in a local restaurant as part of the excursion program but was left out due to shortage of time. However, since the service personnel displayed sympathy, empathy and customer care the couple accepted that such a service episode could happen. The empathetic behaviour of the service personnel was valued and a satisfactory response to the failure incident was obtained.

Recovery action: Upgrading core delivery Service failures in core delivery recovered by upgrading the core service:

Service failure story no. 23 was recovered by upgrading the core service. Unfortunately, a bus broke down on an excursion. However, according to the tour conductor, during the wait the service provider took initiative and a multimedia presentation of the Norwegian fjords was showed in the local cinema. In this way, the core delivery, the excursion, was extended with a highly valued attractive element, the multimedia presentation. According to the tour conductor, the failure turned into a positive experience as the tourists received more than they originally planned and paid for. Thus, this is another example of the phenomenon the "service recovery paradox". This case is also an example of the value of personal initiative and action when a service failure occurs. Although the tour conductor was not empowered to take initiative and solve the situation other than to wait for a new bus to arrive, she took personal initiative and improvised on the "spot" an effective recovery which was highly valued by the tourists. In this way, a satisfactory response was obtained.

\section{Service recovery actions: On the Hurtigruten} while at sea or at harbour

On the Hurtigruten, either at sea or in the harbours, the research entails twenty 29 service failure incidents. The incidents were organised into six sub groups (see Table 2 for organising details). According to the interviewees, eight incidents were recovered. Table 2 provides an overview of the research findings.

Table 2 reads as follows: Five service failure incidents, nos. 18, 27, 3, 37 and 51, which belong to two different service failure sub categories, those of customer needs and requests and tourists' attitudes and behaviour, were recovered by service personnel assistance. Three other service failure incidents, nos. 12, 13 and 30, which belong to the same sub categories, were recovered by upgrading the core delivery. For the purpose of illustration, the table depicts that service failure incidents within four sub categories: jay customers, service personnel, information failures and service failures in core delivery, were not recovered by any recovery action. Descriptive accounts of the service failure incidents will be described next.

\section{Recovery action: Service personnel assistance} Service recoveries by service personnel assistance

Five service failure incidents were recovered by service personnel assistance. Two service stories belong to the sub category "customer needs and requests" and three service failures belonged to the sub category 'tourists' attitudes and behaviours". The recovery actions will be described next.

Customer needs and requests category recovered by service personnel assistance

The service failure stories no. 18 and no. 27 were recovered by service personnel assistance. Story no. 18 concerned the lack of library facilities on the Hurtigruten. According to the tour conductor, a Norwegian couple in their 40s travelled on one of the "old" ships in order to fully experience the "atmosphere" of the "old" Hurtigruta. However, due to climatic conditions of cold and rainy weather, the couple made a request for the provision of library facilities. According to the tour conductor, she managed to meet the requirement that was raised by lending the couple some books and magazines from her own private book collection. By 
Service recovery in a cruise line context - A study on the Norwegian coastal voyage (Hurtigruten).

Table 2. Service recovery actions on the Hurtigruten while at sea or at a harbour

\begin{tabular}{|l|c|c|c|}
\hline \multicolumn{1}{|c|}{ Service Failure Subcategory } & \multicolumn{3}{c|}{ Recovery Actions } \\
\cline { 2 - 4 } & $\begin{array}{c}\text { Economic } \\
\text { compensation }\end{array}$ & $\begin{array}{c}\text { Service personnel } \\
\text { assistance }\end{array}$ & Core delivery \\
\hline Customer needs and requests & & No. 18, No. 27 & No. 12, No. 13 \\
\hline Tourists' attitudes and behaviour & & $\begin{array}{c}\text { No. 3, No. 37, No. } \\
51\end{array}$ & No. 30 \\
\hline Jay customers & & & \\
\hline Service personnel & & & \\
\hline Information failures & & & \\
\hline Service failures in core delivery & & & \\
\hline
\end{tabular}

showing the couple understanding and giving them personalised service, she managed to please the tourist couple. The outcome was a satisfying response to a service failure incident.

Service story 27 concerned a lady who needed a special diet as she was intolerant against some of the food that was served in the ship's restaurant. According to the tour conductor, they tried to meet the requirements of the lady by offering personalised service. However, the lady was not satisfied as she claimed that she had asked for a special diet when buying the round trip in an agency. This is an example of a dissatisfactory response to a service failure incident.

Tourists' attitudes and behaviour category recovered by service personnel assistance

Service failure stories no. 3, 37 and 51 were recovered by service personnel assistance. Service story no. 3 was about a couple from Germany who travelled on one of the "old" ships. They did not approve the gastronomic standards onboard and claimed that the food was "bad". According to the tour conductor, it was not possible to do something "extra" with the food provision onboard. However, by giving the couple more personalised service and by socialising as much as she could with the couple, she managed to take the couple's attention away from the food and enjoy the other elements of the journey.

Story no. 37 was about an old lady who was unlucky and fell down a ladder which she claimed was slippery and blamed the service provider. By simple luck, the lady was not injured except for being beaten black and blue.
However, according to the tour conductor, by paying extra attention to the lady and providing personalised service by showing empathy and care, gradually after recovering from the fall, the lady became a very satisfied traveller.

Story no. 51 concerned a lady who had lost her medicine tablet box which she claimed was removed during the cleaning of the cabin. However, according to the tour conductor, she managed to help the lady by calling a doctor that she knew so the lady could collect the medicine in a pharmacy up north in Stokmarknes (see map in Appendix 1 for geographical information). Thus, the personalised service turned the lady into a very satisfied tourist, more satisfied than if the service failure had not occurred. This is another example of the "service recovery paradox" phenomenon and an example of yet another satisfactory response to a service failure incident.

Recovery action: Upgrading core delivery Service recovery by upgrading the core service Three service failure incidents were recovery by upgrading the core service. The recovery actions belonged to two different sub categories customer needs and requests and tourists' attitudes and behaviour (see Table 2).

Customer needs and requests category recovered by upgrading the core delivery

Service failure stories no. 12 and 13 belong to the customer needs and request category. Story 12 was about a tourist couple who became disappointed by the cabin's location on a lower deck. Because of the location, they were disturbed by the noise from the 
propellers. The couple, who was from Germany, requested a cabin on an upper deck. Fortunately for them, despite the fact that it was the peak summer season, the ship was not fully booked and they received a cabin upgraded. According to the tour conductor, the couple uttered their gratitude for the "extra" service they received on several occasions.

Story no. 13 concerned an Italian group who requested for a change in the food provision towards Mediterranean food. According to the tour conductor, they tried to meet the requirements by making some adjustments in the food provision. In this way they expanded the core product to some extent and the Italians appreciated the personalised service they received since they opposed the "Nordic" kitchen's provision.

Tourists' attitudes and behaviour category recovered by upgrading the core delivery

Service failure story no. 30 was recovered by upgrading the core service. The story was about an American couple who requested for the ship's officers' attendance and socialising with the tourists. The couple had a lot of cruises in their travel portfolio, mostly from the Caribbean waters, fancied the practise on international cruises of being invited to the captain's dinner table. According to the tour conductor, she had to explain to them the demanding tasks of the ship's officers onboard the Hurtigruten such as complicated navigations along the coast and the frequent landings in small coastal cities. However, on a later occasion, she told the ship's captain of the customers' request. The American couple became very satisfied a few days later when they were invited to eat dinner with the captain and the tour conductor. By providing this highly personalised service, the service provider managed to please the tourists by upgrading the core offering, thus creating a satisfactory response to the service failure incident.

The research entails eight recovery actions which were used on the Hurtigruten while either at sea or at harbour(s). The recovery actions used on the Hurtigruten were mostly satisfactory. Obviously, receiving more than the core service is satisfying and when the service employees show empathy and customer care and really do something in the service failure situations, this is highly valued by the customers.

\section{Discussion}

Contrasting the service recovery actions on excursions and on the Hurtigruten

The service recovery actions that were used by the service provider encompass three different actions or strategies: economic compensation, service personnel assistance and upgrading the core delivery. Table 3 depicts the recovery actions on excursions and on the Hurtigruten while at sea or at harbor(s).

Economic compensation is used as a compensating recovery strategy on excursions only. The complainers are simply refunded their personal economic outlays, nothing more. For the service provider, this is a convenient way to compensate for the failures, but for the complainers, who do not receive the core offering of the excursion, this is a compensation strategy at a minimum. According to the interviewees, the complainers assess this as being treated with fairness but do not perceive that the service provider is going the "extra mile" for its customers. As evidenced in the literature, the strategy of economic compensation is frequently used in service failure situations (e.g Bitner et al., 1990; Boshoff, 1997; Hoffman et al., 1995; Hoffman and Chung, 1999).

Service personnel assistance is the most frequently used recovery action which is evidenced in this study. According to the interviewees, the complainers regard the strategy as particularly satisfying because of the human element, as the service personnel engage and actually do something to please and satisfy the complainers. The compensation strategy of service personnel assistance occurs more frequently on the Hurtigruten than on excursions. The reason is that the service personnel on the Hurtigruten is in a better position to actually do something themselves when failures occur than the guides on excursions. When service failures occur on 
Service recovery in a cruise line context - A study on the Norwegian coastal voyage (Hurtigruten).

Table 3. A comparison of the service recovery actions used by the service provider

\begin{tabular}{|l|c|c|c|}
\hline \multicolumn{1}{|c|}{ Service Failure Area } & \multicolumn{3}{c|}{ Recovery Actions } \\
\cline { 2 - 4 } & $\begin{array}{c}\text { Economic } \\
\text { compensation }\end{array}$ & $\begin{array}{c}\text { Service } \\
\text { personnel } \\
\text { assistance }\end{array}$ & Core delivery \\
\hline On excursions & 4 & 3 & 1 \\
\hline $\begin{array}{l}\text { On the Hurtigruten - while at sea or at a } \\
\text { harbour }\end{array}$ & - & 5 & 3 \\
\hline Total & 4 & 8 & 4 \\
\hline
\end{tabular}

excursions, the reason is often that the guides do not perform well in the service role due to a shortage in core service competencies. In a situation like this, there is simply not much to do other than to replace the guide with another on the next excursion. The value of the strategy of service personnel assistance is evidenced in a set of service recovery studies (e.g. Bell and Zemke, 1987; Bitner et al., 1990; Kelley et al., 1993; Johnston, 1995; Boshoff, 1997; Hoffman et al., 1995; Hoffman and Chung, 1999; McDougall and Levesque, 1999).

According to the interviewees, the strategy of upgrading the core service is assessed by the complainers as a satisfactory strategy. In fact, the complainers receive more than they have paid for. For the most part, this recovery action is used as a compensation strategy on the Hurtigruten, only one case is evidenced on excursions. The reason is that it is possible on the Hurtigruten to offer compensation beyond the core offering by, for example providing an upgraded cabin. However, on excursions it is simply difficult to provide more than what is included in the excursion programme. The value of the strategy of upgrading the core delivery is evidenced in a set of service recovery studies (e.g. Kelley et al., 1993; Hoffman et al., 1995; Hoffman and Chung, 1999).

The review of the empirical research on services recovery revealed that the most commonly and frequently used recovery strategies were an apology for the failure, service personnel assistance and/or economic compensation. The research carried out on the Hurtigruten particularly supports previous research on the value of service personnel assistance as a favourable recovery strategy.
Similarly, if a complainer receives a recovery beyond the core offering, this is perceived by the complainers as a satisfactory response to the service failure incident.

The components of effective service recovery: The decisive role of service employees

The answer to research question 1 illuminates the important role of the service employees in the service recovery process. The answer to research question 2 is grounded on the model below which focuses on two components of effective service recovery by service employees, those of competencies and empowerment. The essence is that when the competencies of the service employees are high and a high degree of empowerment exists, effective recovery management will prevail. This logic is grounded in service management theory (e.g. Grönroos, 2006; Kandampully, 2007; among others). The following model is suggested:

Figure 1 illuminates four quadrants. The first (I) quadrant depicts an "unfavourable service recovery" situation because the competencies of the service employees are low and they are not empowered in their service roles. Illustratively, when unskilled students in the summer peak season are hired on short-term employment in the ships' restaurants with restricted authority, they are not in favourable positions to excel in service performance. The second quadrant (II) illustrates an "ineffective service recovery" situation as well because even though the service employees are empowered, they do not possess the competencies needed for carrying out the service roles. When young people, who are often students in the peak season, are employed on short term conditions in the ships' 


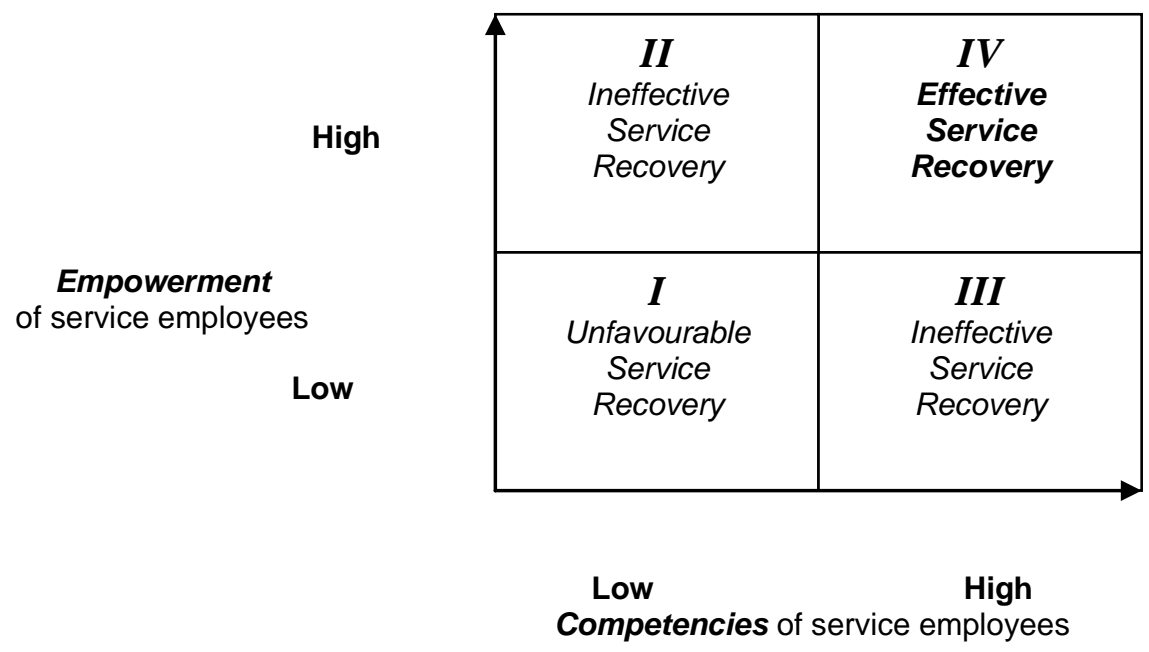

Figure 1. Service recovery: The role of service employees' competencies and empowerment

receptions, they are in principle authorised to provide superior service. However, shortage in service competencies makes them uncertain as how to fully fill the service role. The third (III) quadrant also shows an ineffective service recovery situation. The competencies of the service employees are high. They possess the knowledge, attitudes, skills and behaviour required in order to carry out their service roles at a high standard. However, they are not empowered in their roles, which implies that they are not authorised and enabled to act after the occurrence of service failures. Illustratively, due to a fluctuation in demand and the seasonality problem, the shipping line has a personnel base of substitutes. Some of them have a lot of experience in executing service roles by, for example, having worked as tour conductors on international cruise operations.

However, as they do not have permanent employment on the Hurtigruten, they are not up to date with the rules, regulations and systems in the shipping line. In this way they perceive "distance" to the service provider. Finally, in the fourth quadrant (IV), the conditions for effective service recovery are depicted. Effective service recovery is then grounded on fully empowered service employees with high competencies. This implies that service leadership needs to do the utmost to secure that the competencies of the service employees are high while at the same time providing the resources and equipments needed in order to empower them in their service roles. As the Hurtigruten aims to become a market leader in explorer cruise line operations on a yearly basis, the hiring processes are gradually changed by employing service attendants on a regular basis. In this way, the service employees and service provider tighten the relationships that actually enhance planned competencies building of service attendants and empowering them in the service roles.

\section{Implications}

Theoretical implications

The present study on services recovery on the Hurtigruten has theoretical- and methodological implications. First, the study evidences the robustness of the CIT methodology when examining a phenomenon about which relatively little is known (Gummesson, 2000). Second, the use of a service employee perspective in the study supports previous empirical research which emphasises the important role of high contact service employees as important sources of information who can act as informants of "stories" or "anecdotes" of service failure incidents and associated recoveries (Grönroos, 2006). Thus, the interactive role of front stage personnel is decisive for quality improvements and effective complaint management (e.g. Bettencourt and Gwinner, 1996). Third, the complexity of many service processes, as on the Hurtigruten, 
supports the view that a classification scheme of service failures has to be contextualised, i.e. the scheme has to be developed according to how the services are delivered (e.g. Edvardsson, 1992). In the study reported, this implies the development of targeted service failure classification schemes. Fourth, the study supports the view of customer information as important sources of information for the purpose of quality development and improvements (e.g. Gustavsen et al., 1999; Grönroos, 2006). Fifth, the value of service employees' initiatives and actions for effective service recovery is confirmed in this study. However, the study has implications for management as well.

\section{Implications for management}

One lesson to be learned from the study is that shipping line management should continue to improve the quality of the service product. This is a challenging task when service delivery processes are quite complex and involve a series of direct interactions between the tourists and the service personnel whose performances are likely to vary from one day to another. However, two areas seem to require special attention from management on the Hurtigruten. First, the planning and execution of excursions, and second, the service operations in the ships' restaurants.

The planning and execution of an excursion is a rather complex task. Imagine the North Cape excursion which includes a bus trip to the plateau, eating a meal in an often overcrowded restaurant served by young inexperienced waiters, scrambling for a seat in the cinema to watch a video production, cue in the souvenir shop and returning by bus to the ship after several hours. Obviously, this highly complex service delivery process is demanding for any (tour) service provider. In order to enhance quality on excursions, two points seem important. First, the hiring and selection of service employees to front line positions, and second, the training of service attendants. The study reveals that in some cases service attendants are uncertain what to do when service failures occur. This implies that management needs to address the issues of competency building and empowerment in order to prepare the service employees for challenging service processes.

The ship's restaurant is a place where service failures are likely to occur. An inspection of the service failure and recovery list in Appendix 2 reveals that two distinct areas need inquiry. First is the hiring, selection and training of service attendants. If a service failure is caused by a rude and impolite service attendant this obviously has to do with weakness in the recruitment and training processes. The second is a thorough examination of the food preferences of the international travelers. Although the gastronomic trends move towards an international cuisine, management must remember that most of the tourists on the Hurtigruen are beyond their 50s and, according to the interviewees, are often somewhat conservative in their food habits, preferences and wishes. As the meals served seem to be an important part of the core Hurtigruten product, the menu should be given special attention by management in order to reveal changes in preferences and wishes.

\section{Conclusions}

As evidenced in service management theory and research, service failures are an inevitable part of service processes, particularly in highcontact services like such as cruise operations. Different kinds of service failures may occur, and in the service literature different kinds of service failure typologies are outlined and discussed. Obviously, when service failures occur, there is a strong need for effective service recovery management. Effective service recovery management may encompass different kinds of service recoveries, including those of customer-, process- and service employees' recovery (Michel et al., 2009). In service recovery research, a set of service recovery actions has been identified in order to satisfy and retain customers. In the research reported in this paper, the actions of economic compensation, service employee assistance and upgrading the core offering are the ones used in a set of service failure incidents on the Hurtigruten. The most valued by the customers is when service employees actually do something after the occurrence of service failures. Thus, the decisive role of service 
employees in service recovery management is confirmed in the research reported in this paper. As argued, in order to perform the service role effectively, the service employees need both competency and empowerment.

The research, however, may suffer from challenges and limitations. One issue to debate is the selection of informants. In the study carried out, only regulars were included in the sample. The sample may have also been extended to include part-time tour conductors. Some of them had been in such positions for quite a long period of time and could have contributed positively to the research finding. However, the regulars were considered to be the most knowledgeable service employees on service failure processes. Another issue is the use of a service employee perspective in the collection of service failure incidents. By employing this perspective, the information collected is "filtered" as the information originates from the dissatisfied tourists. An alternative would have been to employ a customer perspective which could have been beneficial in order to obtain first-hand service failure information from the tourists. However, the choice of perspective was taken due to the entire resource situation, primarily a restricted economy. However, when collecting "stories" of service recovery actions or strategies, the tour conductors are first hand informants of such incidents because they possess a good knowledge on what the service provider did in order to compensate the service failure incidents. A third issue is the time of data collection. Nonetheless, at the time of data collection, the strategic choice was made to turn the Hurtigruten into a world class explorer cruise line company, and the old ships were substituted with new ones. Thus, at the time of the study the core service offering and supplementary services are quite similar to the total attraction product that is the Hurtigruten today. Thus, the relevance and validity of the data is still considered high even today.

However, more research on services recovery is needed on the Hurtigruten. One option is to conduct a follow-up study by employing a service employee perspective. By doing this, completely up to date data may be collected and analysed. Such data would also be beneficial in order to carry out a comparative study and examine changes in service performance. Another option is to change the research perspective by using a customer perspective in collecting "stories" or "anecdotes" of service failure incidents. Obviously, a customer perspective may imply a sample of subjects, which may favour a quantitative approach to research. In this way a quantitative study may supplement the findings in the qualitative study reported in this paper. Another option is to expand the research focus by including more cruise line operators in a study. In this way, the research findings would be beneficial for the cruise industry as a whole.

\section{Bibliography:}

Armistead, C. G., Clark, G. and Stanley, P. (1995). Managing service recovery. Cranfield School of Management, Cranfield.

Bamford, D. and Xystouri, T. (2005). A case study of service failure and recovery within an international airline. Managing Service Quality 15(3), 306-322.

Bejou, D., Edvardsson, B. and Rakowski, J. P. (1996). A critical incident approach to examining the effects of service failures on customer relationships: The case of Swedish and US airlines. Journal of Travel Research 35(1), 35-40.

Bejou, D., and Palmer, A. (1998). Service failure and loyalty: An exploratory empirical study of airline customers. Journal of Services Marketing 12(1), 7-22.

Bell, S. J., and Luddington, J. A. (2006). Coping with customer complaints. Journal of Service Research 8(3), 221-233.

Bell, C. R., and Zemke, R. E. (1987). Service breakdowns: The Road to recovery. Management Review 76(10), 32-35.

Berry, L. L., and Parasuraman, A. (1992). Prescriptions for service quality revolution in America. Organisational Dynamics 20(4), 5-15.

Bettencourt, L. A. and Gwinner, K. (1996). Customization of the service experience: The role of the frontline employee. International Journal of Service Industry Management 7(2), 3-20.

Biederman, P. S. (2008). Travel and tourism. An industry primer. Prentice Hall. 
Service recovery in a cruise line context - A study on the Norwegian coastal voyage (Hurtigruten).

Bitner, M. J., Booms, B. H., Tetreault, M. S. (1990). The service encounter: Diagnosing favorable and unfavorable incidents. Journal of Marketing 54(1), 7184.

Bitner, M. J., Booms, B. H., Mohr, L. A. (1994). Critical service encounters: The employee's viewpoint, Journal of Marketing 58(4), 95-106.

Booth, W. C., Colomb, G. G., Williams, J. M. (2003). The craft of research. The University of Chicago Press.

Boshoff, C. (1997). An experimental study of service recovery options. International Journal of Service Industry Management 8(2), 110-130.

Boshoff, C. P., and Allen, J. (2000). The influence of selected antecedents on frontline staff's perception of service recovery performance. International Journal of Service Industry Management 11(1), 6390.

Boshoff, C., and Leong, J. (1998). Empowerment, attribution and apologising as dimensions of service recovery: An experimental study. International Journal of Service Industry Management 9(1), 24-47.

Boshoff, C., Staude. G. (2003). Satisfaction with service recovery: Its measurement and its outcomes. South American Journal of Business Management 34(3), 9-17.

Bowen, D. E., Johnston, R. (1999). Internal service recovery: Developing a new construct. International Journal of Service Industry Management 10(2), 118-131.

Brown, S. W., Fisk, R. P., Bitner, M. J. (1994). The development and emergence of services marketing thought. International Journal of Service Industry Management 5(1), 21-48.

Chung, B., Hoffman, K. D. (1998). Critical incidents: Service failures that matter most. Cornell Hotel and Restaurant Administration Quarterly 39(3), 66-71.

Clark, M., Riley, M., Wilkie, E.Wood, R. C. (1998). Researching and writing dissertation in hospitality and tourism. London: International Thompson Business Press.

Craighead, C. W., Karwan, K.R., Miller, J. L. (2004). The effects of severity of failure and customer loyalty on service recovery strategies. Production \& Operations Management 13(4), 307-321.

Czepiel, J. A. (1990). Service encounters and service relationships: Implications for research. Journal of Business Research 20, 13-21.

D'Aveni, R. (1994). Hypercompetition: The dynamics of strategic manoeuvring. Basic Books, New York, NY.

De Jong, A., de Ruyter, K. (2004). Adaptive versus proactive behaviour in service recovery: The role of self-managing teams. Decision Sciences 35(3), 457491.

Duffy, J.A.M., Miller, J.M., Bexley, J. B. (2006). Banking customers varied reactions to service recovery strategies. International Journal of Bank Marketing 24(2), 112 132.

Durvasuta, S., Lysonski, S., Mehta, S. C. (2000). Business-to-business marketing service recovery and customer satisfaction issues with ocean shipping lines. European Journal of Marketing 34(3/4), 433-452.

Eccles, G. and Durand, P. (1998). Complaining customers, service recovery and continuous improvement. Managing Service Quality 8(1), 68-71.

Edvardsson, B. (1992). Service breakdowns: A study of critical incidents in an airline. International Journal of Service Industry Management 3(4), 17-29.

Etzel, M. J., Silverman, B. I. (1981). A managerial perspective on directions for retail consumer dissatisfaction research. Journal of Retailing 57(3), 124-136.

Fielding, N. (1997). Qualitative interviewing. In Gilbert, N. (ed.) Researching social life. London: Sage Publications.

Flanagan, J. C. (1954). The critical incident technique. Psychological Bulletin 51, 327-357.

Goldstein, S., Johnston, R., Duffy, J. A. M., Rao, J. (2002). The service concept: The missing link in service design research. Journal of Management 20(2), 121-134.

Goodwin, C., Ross, I. (1990). Consumer evaluations of responses to complaints: What's fair and why? Journal of Consumer Marketing 7(2), 39-47.

Gross, G., Caruso, B., Conlin, R. (2007). A look in the mirror: The VOC scorecard. New York, NY: McGraw-Hill.

Grove, S. J., Fisk, R. P. (1992). Observational data collection methods for services marketing: An overview. Journal of the Academy of Marketing Science 20(3), 217-224. 
Grönroos, C. (1988) Service quality: The six criteria of good perceived service quality. Review of Business, 9(Winter), 10-13.

Grönroos, C. (2000). Service management and marketing. A customer relationship management approach. Chichester: John Wiley \& Sons, Ltd.

Grönroos, C. (2006). Service management and marketing. Customer management in service competition. Chichester: John Wiley \& Sons, Ltd.

Gummesson, E. (2000). Qualitative methods in management research. Sage Publications, Inc

Gustavsen, A., Ekdahl, F., Edvardsson, B. (1999). Customer focused service development in practice. International Journal of Service Industry Management 10(4), 344-358.

Harris, L. C., Ogbonna, E. (2006). Service sabotage: A Study of antecedents and consequences. Journal of the Academy Marketing Science 34(4), 543-558.

Hart, C. W. L., Heskett, J. L., Sasser, W. E. (1990). The profitable art of service recovery. Harvard Business Review 68(4), 148-156.

Heskett, J. L., Jones, T. O., Loveman, G.W., Sasser Jr., W. E., Schlesinger, L. A. (1994). Putting the service-profit chain to work. Harvard Business Review 72(2), 163-72.

Hoffman, K. D., Bateson, J. E. G. (1997). Essentials of services marketing. The Dreyden Press.

Hoffman, K. D., Chung, B. G. (1999). Hospitality recovery strategies: Customer preference versus firm use. Journal of Hospitality \& Tourism Research 23(1), 71-84.

Hoffman, K. D., Kelley, S. W., Rotalsky, H. M. (1995). Tracking service failures and employee recovery efforts. Journal of Services Marketing 9(2), 49-61.

Hurtigruten (1999). Strategic choices after 2001. Company report.

Johannessen, A., Kristoffersen, L., Tufte, P. A. (2004). Forskningsmetode for økonomisk-administrative Fag. Abstrakt Forlag.

Johnston, R. (1995). Service failure and recovery: Impact, attributes and process. Advances in Services Marketing and Management, Volume 4, 211-228.

Johnston, R. (2001). Linking complaint management to profit. International
Journal of Service Industry Management 12(1), 60-69.

Johnston, R., and Clark, G. (2008). Service operations management., Essex: Pearson, $3^{\text {rd }}$ ed.

Johnston, R., Michel, S. (2008). Overcoming recovery myopia: Three types of service recovery. International Journal of Operation \& Production Management 28(1), 79-99.

Kandampully, J. S. (2007). Services management. The New Paradigm in Hospitality. Prentice Hall.

Keaveney, S. M. (1995). Customer switching behaviour in service industries: An exploratory study. Journal of Marketing 59(2), 71-82.

Kelley, S. W., Hoffman, K. D., Davis, M. A. (1993). A typology of retail failures and recoveries. Journal of Retailing 69(4), 429-452

Kinnear, T. C., Taylor, J. R. (1991). Marketing research: An applied approach. New York: McGraw-Hill.

Krippendorf, K. (1980). Content analysis: An introduction to its methodology. London: Sage Publications.

Lewis, B. R., Clacher, E. (2001). Service failure and recovery in UK theme parks: The employees' perspective. International Journal of Contemporary Hospitality Management 13(4), 166-175.

Lewis, B. R., Entwistle, T. W. (1988). Managing the service encounter: $A$ focus on the employee. International Journal of Service Industry Management 1(3), 4152.

Lewis, B. R., McCann, P. (2004). Service failure and recovery: Evidence from the hotel industry. International Journal of Contemporary Hospitality Management 16(1), 6-17.

Lewis, B. R., Spyrakopoulos, S. (2001). Service failures and recovery in retail banking: The customers' perspective. International Journal of Bank Marketing 19(1), 37-48.

Lorenzoni, N., Lewis, B. R. (2004). Service recovery in the airline industry: A crosscultural comparison of the attitudes and behaviours of British and Italian front-line personnel. Managing Service Quality 14(1), 11-25.

Lovelock, C., Wright, L. (1999). Principles of service marketing and management. Prentice Hall. 
Service recovery in a cruise line context - A study on the Norwegian coastal voyage (Hurtigruten).

Maxham, J. G. (2001). Service recovery's influence on customer satisfaction, wordof-mouth, and purchase intentions. Journal of Business Research 54(1), 1124.

Maxham, J. G., Netemeyer, R. G. (2002). A longitudinal study of complaining customers' evaluations of multiple service failures and recovery efforts. Journal of Marketing 66(4), 57-71.

McCracken, G. (1988). The long interview. A Sage University Paper.

Mattila, A. S. (1999). An examination of factors affecting service recovery in a restaurant setting. Journal of Hospitality and Tourism Research 23(3), 284-298.

Mattila, A. S (2001). The effectiveness of service recovery in a multi-industry setting, The Journal of Services Marketing 15(7), 583596.

McDougall, G. H. G., Levesque, T. J. (1999). Waiting for service: The effectiveness of recovery strategies. International Journal of Contemporary Hospitality Management 11(1), 6-15.

Mehmetoglu, M. (2004). Kvalitativ metode for merkantile fag. Fagbokforlaget.

Merriam, S. B. (1998). Qualitative research and case study applications in education. Jossey-Bass Publishers.

Michel, S. (2001). Analysing service failures and recoveries: A process approach. International Journal of Service Industry Management 12(1), 20-33.

Michel, S., Bowen, D., Johnston, R. (2009). Why service recovery fails: Tensions among customer, employee and process perspectives. Journal of Service Management, 20(3), 253-273.

Miller, J. L., Craighead, C. W., Karwan, K. R, (2000). Service recovery: A framework and empirical investigation. Journal of Operations Management 18(4), 387-400.

Nerdrum, P. (1998). Mellom sannhet og velferd. Etiske dilemmaer i forskning belyst ved et eksempel. Notat - Høgskolen i Oslo, avdeling for Økonomi-, Kommunal- og Sosialfag.

Pugh, S. D, Dietz, J., Wiley, J. W. (2002) Driving service effectiveness through employeecustomer linkages. Strategic Management Journal 16(1), 15-37.

Rust, R. T., Zeithaml, V. A., Lemon, K. N. (2000). Driving customer equity. How customer lifetime value is reshaping corporate strategy. New York: The Free Press.

Schneider, B., White, S. (2004). Service quality research perspectives. Thousand Oaks, $C A$ : Sage.

Seligman, M. E. P. (1972). Learned helplessness. Annual Review of Medicine, 23, 407-412.

Skaalsvik, H. (2011). Service failures in a cruise line context: Suggesting categorial schemes of service failures. European Journal of Tourism Research 4(1), 25-44.

Smith, A. K., Bolton, R. N., Wagner, J. (1999). A model of customer satisfaction with service encounters involving failure and recovery. Journal of Marketing Research 36, 356-372.

Spreng, R. A., Harrell, G. D., Mackoy, R. D. (1995). Service recovery: Impact on satisfaction and intentions. Journal of Services Marketing 9(1), 15-23.

Susskind, A. M. (2002). "I told you so!" Restaurant customers'

word-of-mouth communication patterns. Cornell Hotel \& Restaurant Administration Quarterly 43(2), 75-85.

Swanson, S. R. and Kelley, S. W. (2001). Service recovery attributions and word-of-mouth intentions. European Journal of Marketing 35(1/2), 194-211.

Tax, S. S., Brown, S. W. (1998). Recovering and learning from service failure. Sloan Management Review 40(1), 75-88.

Tax, S. S., Brown, S. W., Chandrashekaran, M. (1998). Customer evaluations of service complaint experiences: Implications for relationship marketing. Journal of Marketing 62(2) 60-76.

Veal, A. J. (1997). Research methods for leisure and tourism. Pitman Publishing.

Veal, A. J. (2006). Research methods for leisure and tourism. Pitman Publishing.

Yin, R. K. (2003). Case study research: Design and methods. Sage Publications, London.

Yukl, G. (2002). Leadership in organisations. Prentice Hall International Editions.

Zeithaml, V. A., Berry, L. L., Parasuraman, A. (1996). The behavioral consequences of service quality. Journal of Marketing 60(2), 31-46.

Zemke, R., Connellan, T. (2001). E- service: 24 ways to keep your customers when the competition is just one click away. New York: AMACON. 
Appendix 1. Informative details and the sailing route of the Hurtigruten

On the $2^{\text {nd }}$ July 1893 , the Norwegian steamship D/S Vesteraalen embarked on a voyage from Trondheim to Hammerfest. About 70 hours later the ship arrived successfully in Hammerfest. Three weeks earlier the Norwegian Parliament had agreed upon a proposal to establish a coastal route along the Norwegian coastline from Trondheim to Hammerfest. This was a new and quite astonishing idea, to sail both day and night along one of the most weather-beaten coasts in the world under all climatic conditions. Despite skepticism and even severe resistance from experts in sea transport in Norway, the Hurtigruten became a logistic success in sea transport. In 1898, the route was extended to Bergen down south, and from 1908 to Kirkenes up north. Today, more than a 100 years later, the Hurtigruten has become a tourist attraction product of significant importance in Norway comprising 2500 nautical miles, 34 ports of call, 11 ships and an eleven-day return voyage Bergen - Kirkenes.

\section{Sailing route $(2011)$}

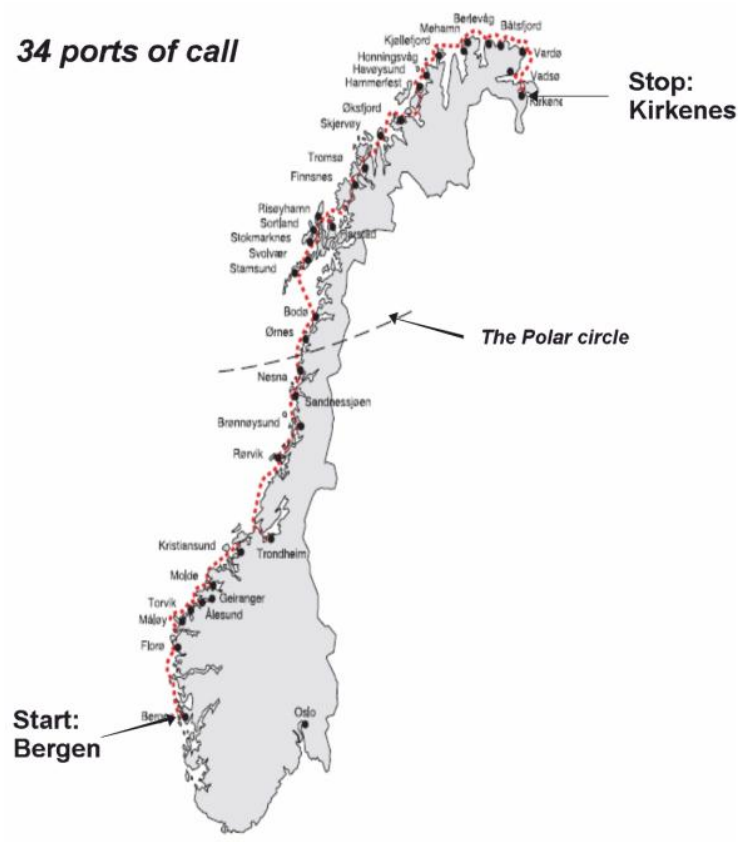

Appendix 2. Service Failure and associated recovery list: The Hurtigruten case

1. Excursion. Fog on the North Cape. Weather forecast information not provided. No recovery. Service leadership failed by the lack of information procedure and system. Information failure.

2. Excursion. Kristiansund - Molde. Dinner not served in a local restaurant. A tourist couple in the 40s complained. Service failure in core delivery. Recovery by service employee assistance. Free meal. Customer response: Satisfactory.

3. Hurtigruten. Restaurant. "Bad" food. Food complaint. Tourists' attitude. Recovery by service employee assistance. Personalized service. Customer response: Satisfactory.

4. Hurtigruten. Restaurant. Noise. Unable to hear announcements on the loud speaker system. Information failure. No recovery. Service leadership failed by the lack of information procedure and system.

5. Hurtigruten. Service personnel. Lack of language skills. French and Italian tourist group complained. Service personnel competency. No recovery. Service leadership failed by the lack of quality in hiring and training procedures.

6. Hurtigruten. The provision of TVchannels onboard. "Only" CNN available. Customers' request for an expansion of the provision of international TV channels. No recovery. Service leadership failed by shortage in the core delivery.

7. Hurtigruten. The lack of entertainment. Tourists' asked for entertainment onboard such as folk music. Customers' request. No recovery. Service leadership failed by shortage in the core delivery.

8. Same as 7. No recovery.

9. Excursion. Fully booked. The tourists had booked abroad. Information failure. No recovery.

10. Excursion. Tourists came too late to participate on the excursion. Customer error failure. Recovery by economic compensation. Customer response: Not satisfactory.

11. Excursion. Unprofessional guide in Tromsø. Competency failure. No recovery.

12. Hurtigruten. Cabin. Location. Customer request for cabin change due to noise. 
Service recovery in a cruise line context - A study on the Norwegian coastal voyage (Hurtigruten).

Recovery by upgrading the core service. Customer response: Satisfactory.

13. Hurtigruten. Restaurant. The menu. Tourists' asked for a change in menu. Customer request. Recovery by upgrading the core service. Customer response: Satisfactory.

14. Excursion. Bad weather. Lack of weather forecast information. Information failure. No recovery. Service leadership failed by the lack of information procedure and system.

15. Hurtigruten. Cabin. Check out at 9 a.m. in Bergen. Customers' request for a later check-out. Concerns shortage in core delivery. No recovery.

16. Excursion. Overbooked. Service failure by a service employee. Competency failure. Recovery by economic compensation. Customer response: Not satisfactory.

17. Excursion. Tourists had to wait for a new bus. Lack of information. Information failure. Recovery by service employee assistance. Customer response: Not satisfactory.

18. Hurtigruten. Tourists' requested for provision of library services. Customer request. Recovery by service personnel assistance. Customer response: Satisfactory.

19. Hurtigruten. Cabin. Location. Customer request for a cabin change due to noise. No recovery.

20. Hurtigruten. Lack of service mindedness by service personnel. Service personnel competency. Service employees failed in the execution of the service role. No recovery.

21. Excursion. An unprofessional guide in action. Service employee failed in the execution of the service role. Competency failure. No recovery.

22. Excursion. Norwegian lady had lost her prescription. Customer error failure. Recovery by service employee assistance. Customer response: Satisfactory.

23. Excursion. Bus collapsed. Geiranger. Service failure in core delivery. Recovery by upgrading the core product. Customer response: Satisfactory.

24. Hurtigruten. Restaurant. Unfavourable service personnel behaviour. Service personnel competency. No recovery.
25. Excursion. North Cape. Service Personnel. Unfavourable service attitude by service personnel. Competency failure. No recovery. Service leadership failure by the lack of hiring and training procedures and programmes.

26. Hurtigruten. Cabin. Location. Customer request for cabin change due to noise from the propellers. No recovery.

27. Hurtigruten. Restaurant. A customer's request for special food/diet. Recovery by service personnel assistance. Customer response: Not satisfactory.

28. Hurtigruten. Restaurant. The menu. Tourists ate too much and got sick. Customers' behaviour. No recovery.

29. Hurtigruten. Entertainment onboard perceived as noise by a tourist group. Customers' attitudes. No recovery.

30. Hurtigruten. Service personnel. Tourists wanted more attendance of senior ship officers in the tourism "areas" on the ship. About shortage in core delivery. Recovery by upgrading the core service. Customer response: Satisfactory.

31. Excursion. Unprofessional guide in action. Trondheim. Competency failure. No recovery.

32. Excursion. High price on the excursion as perceived by the tourists. No recovery. Service leadership is responsible for pricing strategies. Service failure ragbag category.

33. A "jay" customer. "Everything" was wrong onboard the coastal voyage. No recovery.

34. Hurtigruten. Restaurant. Two children made disturbance and created noise. A couple in their 60s complained. Customers' attitude. No recovery.

35. Hurtigruten. Restaurant. The menu. Dissatisfaction with the menu. Tourist attitude. No recovery.

36. Excursion. The mix of travellers. An English couple did not want to travel on the same bus as Germans on an excursion because of $2^{\text {nd }}$ world war experience. Service failure - ragbag category. No recovery.

37. Hurtigruten. A lady from Germany fell down a ladder. Customer behaviour. Recovery by service employee assistance. Personalized service. Customer response: Satisfactory. 
38. Excursion. The bus driver. Lack of service attitude. Competency failure. No recovery.

39. Excursion. An unprofessional guide in action. The North Cape. Competency failure. No recovery.

40. Hurigruten. Restaurant. "Poisoned" food. Jay customer. No recovery. A situation caused by "problematic" customers.

41. Excursion. A high price as perceived by tourists. No recovery. Service leadership is responsible for pricing strategies. Service failure - ragbag category.

42. Hurtigruten. The check- in procedure in Bergen. Logistic problems. Customer dissatisfaction by the queue. About shortage in core delivery. No recovery.

43. Hurtigruten. The check-out procedure in Bergen. Customer dissatisfaction due to the many tourists leaving the ship at about the same time. About shortage in core delivery. No recovery.

44. Excursion. North Cape. An unprofessional guide in action. Competency failure. No recovery.

45. Hurtigruten. A film team onboard. The tourists had to move from their seating.
No information provided ahead of the arrangement. Information failure. No recovery. 46. Hurtigruten. The change of travel route in order to maintain the time schedule. About core delivery. No recovery.

47. Excursion. Tour only outside the church. The tour inside the church was left out of the programme. Service failure in core delivery. No recovery.

48. Excursion overbooked. A mistake done by the service personnel. Competency failure. Recovery by economic compensation. Customer response: Not satisfactory.

49. Excursion. A couple was too late for the bus departure. Customer error failure. Recovery by economic compensation. Customer response: Not satisfactory.

50. Hurtigruten. Drinking behaviour by male locals caused dissatisfaction by fellow travellers. Travellers' behaviour. No recovery. The lack of service employees' initiatives and actions.

51. Hurtigruten. A tourist had lost the medicine. Tourist behaviour. Recovery by service employee assistance. Customer response: Satisfactory. 